\title{
Enhancing the climate resilience of coffee production
}

\author{
Authors \\ Phoebe Bracken ${ }^{1}$ \\ Paul J Burgess ${ }^{1}$ \\ Nicholas T Girkin ${ }^{1 *}$ \\ 1. School of Water, Energy and Environment, Cranfield University, UK \\ ${ }^{*}$ Corresponding author: $\underline{\text { n.t.girkin@cranfield.ac.uk }}$
}

\section{Abstract}

Climate change is adversely affecting coffee production, impacting both yields and quality. Coffee production is dominated by the cultivation of Arabica and Robusta coffee, species that represent $99 \%$ of production, but both species will be affected by climate change. Sustainable management practices that can enhance the resilience of production are urgently needed, as coffee production supports the livelihoods of over 25 million people across the world, the majority of whom are smallholder farmers located in the coffee belt spanning the tropics. We conducted a systematic review, identifying 78 studies that describe agro-ecological practices that have potential to enhance climate resilience. Adverse environmental impacts include a reduction in area suitable for production, lower yields, increased intensity and frequency of extreme climate events, and greater incidence of pests and diseases. Potential environmental solutions include altitudinal shifts, the introduction of new, more resilient cultivars, altering agrochemical inputs, and integrating agroforestry. However, financial, environmental and technical constraints limit the availability of many of these approaches to farmers, particularly smallholder producers. There is therefore an urgent need to address these barriers through appropriate policy mechanisms in order to continue meeting growing demand for coffee.

Keywords: climate change; coffee; crop yield; agroforestry; regenerative agriculture

\section{Highlights}

- Climate change will adversely affect all current coffee production areas.

- Mitigating effects will require short and long-term solutions.

- Long-term solutions include altitudinal shifts and incorporating new climate-resilient genotypes.

- In the shorter-term, agroforestry can bring wide-ranging benefits for increasing climate resilience, and may enhance yields and crop quality.

- Ensuring environmental solutions are equally accessible to all producers is a priority. 


\section{Introduction}

Coffee is of global economic, cultural and social importance, grown in more than 60 countries by 25 million farmers, often smallholders, and supporting the livelihoods of 120 million people (Chengappa et al., 2017; Läderach et al., 2017; Rahn et al., 2014). Despite there being over 100 species of coffee, Robusta (Coffea canephora Pierre ex Froehner) and Arabica (Coffea arabica L.) species represent $99 \%$ of commercial the coffee trade (Davis et al., 2019). Coffee is produced in the 'coffee belt' across Central and South America, Africa and Asia (Reay, 2019; Ovalle-Rivera et al., 2015; Bunn et al., 2015b). Production across the region is likely to be adversely impacted by climate changes. There is therefore a critical need to build on-farm climate resilience and tailor such solutions to local social and environmental contexts (IPCC, 2012; Shapiro-Garza et al., 2020).
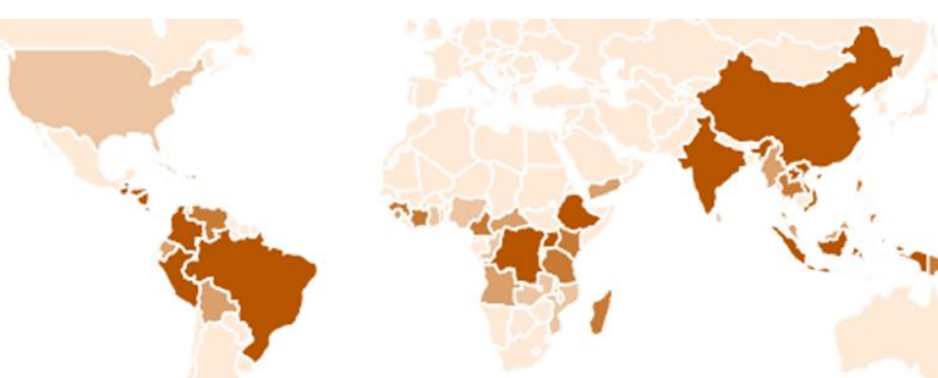

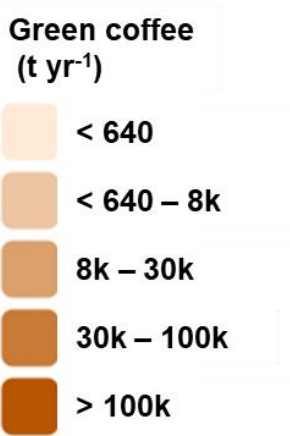

Figure 1: Global green coffee bean production $\left(\mathrm{t} \mathrm{yr}^{-1}\right), 2010$ to 2019 by country of origin (FAOSTAT 2019).

Optimal conditions for coffee growth are species-dependent. Arabica, representing $70 \%$ of coffee production and producing the highest-grades of coffee, is more climate-sensitive than Robusta, and grows best at altitudes of 1300-1500 masl (metres above sea level) (Läderach et al., 2017; Bunn et al., 2015b). The optimal mean annual temperature range for Arabica is 18 to $22^{\circ} \mathrm{C}$, compared with the warmer range of 22 to $26^{\circ} \mathrm{C}$ for Robusta, allowing easier cultivation at lower altitudes (Zullo et al., 2011; Davis et al., 2012). Temperatures beyond these may prevent blossoming and accelerated ripening, affecting flavour profiles, whilst heatwaves and frosts can cause significant yield and quality declines (Santos et al., 2015; Camargo, 2010). Quality is typically measured by electronic sensors or coffee tasters who score samples on tasting notes (Vietoris et al., 2015).

The intensity and seasonal variation in precipitation are important in coffee plant development as the crop is typically produced in rainfed systems. Regular rainfall facilitates flowering, but it can be advantageous for dry weather as the fruits develop prior to harvesting and drying (Gidey et al., 2020). The distinction between dry and wet seasons is especially important in Arabica cultivation, as it is less tolerant of variable precipitation than Robusta (Reay, 2019). The patterns of rainfall and temperature in existing coffee areas will shift under climate change, threatening the viability of coffee production (IPCC, 2018; Camargo, 2010; Chengappa et al., 2017). Bunn et al (2015b) predict that increasing mean annual temperatures, more variable patterns of rainfall and increased likelihood of extreme weather events will decrease the global area suitable for Arabica coffee cultivation by at least half by 2050, with East Africa and Asian island states being the only major areas where the suitable area will increase. Simultaneously, more indirect effects of climate change on coffee production, such as increased disease outbreaks and climate extremes, are already having observable impacts on coffee (Chengappa et al., 2017). Nonetheless, selecting 
coffee cultivars resistant to such pests could enable the successful production of coffee under otherwise unfavourable environmental conditions (Davis et al., 2019).

Climate change is placing several stresses on coffee production systems that are driving innovative adaptation measures to mitigate these negative impacts on yield and quality (Eakin et al., 2014). Coffee plants take at least three years until they begin to bear fruit and, as a perennial crop, plantations typically last 30-50 years (Davis et al., 2012; Läderach et al., 2017). Field-level management decisions, therefore, require foresight and potentially more future planning than annual crops' cultivation (Läderach et al., 2017). Examples of such practices include agroforestry, intercropping, improved irrigation strategies, relocating areas of production, and the development and selection of new coffee cultivars (Pappo et al., 2021; Chengappa et al., 2017; Nesper et al., 2019). To date, there has been no systematic review of the effectiveness of these techniques in enhancing coffee crop climate resilience. The effectiveness of coffee production's climate resilience depends on understanding local context, barriers to implementation and crucially, necessitates the inclusion of coffee producers in the process (Quiroga et al., 2020; Castellanos et al., 2013).

The aim of this study is therefore to identify soil, water and crop management practices that can create more climate resilient coffee production in the coming decades. Our central hypothesis is that the adoption of specific management practices can enhance the climate resilience of coffee production. Optimal resilience-building strategies will need to be multifaceted, draw on understandings of local and global changes, and utilise holistic perspectives of coffee production ecosystems.

101

102

103

104

105

106

107

108

109

110

111

112

113

114

115

116

117

\section{Methodology}

Using the Scopus database (www.scopus.com), we conducted a systematic review to identify and collate papers relating to field-management practices that have the potential to build resilience, and mitigate the impact of climate change on coffee production (Pickering et al., 2015). Systematic reviews are multi-stage processes (Figure 2: Systematic review process. ) involving specified criteria for the inclusion and exclusion of papers (Hammersley, 2001). Keywords were identified from the aim and objectives to create the following search strings with Boolean operators, searching in the title, abstract and keyword section of documents: 'climate change' AND 'adaptation' OR 'mitigation' OR 'management' AND 'coffee'. The initial search yielded 240 papers. These documents identified from this search were collated into a database to record the processes of inclusion and exclusion. Of the total papers found in the initial search, 175 were excluded through screening. This included the removal of duplicate papers $(n=3)$, papers that were inaccessible $(n=10)$, non-English language $(n=3)$, non-peer reviewed publications (e.g. conference papers, $n=15$ ), and studies identified as not being relevant based on the contents of the abstract $(n=144)$. An additional 13 papers identified from the reference lists of the remaining papers were also selected based on their relevance, leading to a total of 78 studies. 
Papers from search

string*

$\mathbf{n}=\mathbf{2 4 0}$
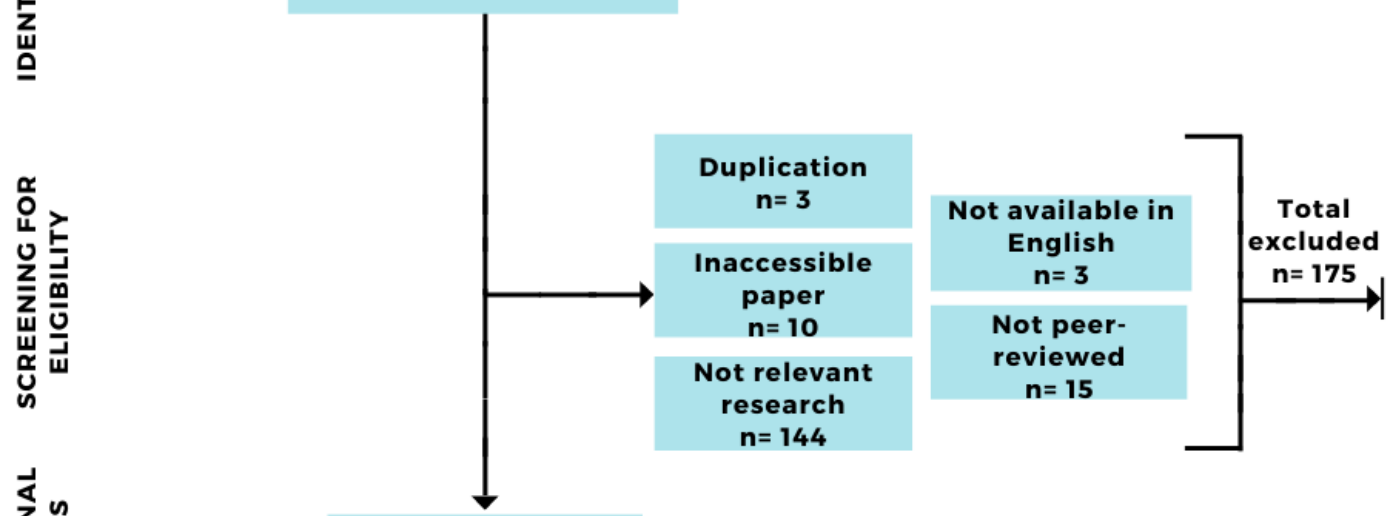

Total papers included $\mathbf{n}=78$

Figure 2: Systematic review process. *search strings: ‘climate change' AND 'adaptation' OR 'mitigation' OR 'management' AND 'coffee'.

Each paper was subsequently categorised into themes, including impacts of climate change and coffee production, soil water and crop management, agroforestry, and policy context and barriers to implementation, with the themes drawn from the studies themselves (Hammersley, 2001). The approach taken to understanding coffee's climate resilience opportunities has its limitations. Using Scopus is likely to omit the experiences of coffee producers themselves, as those authoring papers tend to be in academia or industry. The exclusion of grey literature and non-English language papers in the review represents a further omission of knowledge that has the potential to inform this study and discussion. Hence, there is a potential gap in understanding of those facing the effects of climate change and their direct experience of adapting coffee production.

\section{Climate change and coffee production}

Temperature and drought responses of coffee

Climate change, particularly changes in precipitation and temperature will substantially affect coffee production by directly impacting coffee crops. The effects of drought on coffee plants are wide-ranging and include reduced production of new leaves, chlorosis, reduced stem elongation, a reduction in the number of fruiting nodes per tree, fewer fruits per note, and reduced seed size, and reduced bean quality (Carr, 2000). Although periods of water stress are necessary for the development of flower buds, consistent temperatures above the optimal ranges of 18 to $22^{\circ} \mathrm{C}$ for Arabica, and 22 to $26^{\circ} \mathrm{C}$ for Robusta can reduce crop growth and cause damage to the crop physiology, particularly during flower bud development (Zullo et al., 2011; Carr, 2001). However, vulnerability to extreme temperatures and droughts differs between cultivars bred for specific characteristics, such as deeper-rooting systems that increase access to scarce water resources and earlier stomatal closure (DaMatta \& Ramalho, 2006). There are also more indirect effects of 
extreme temperatures and drought, such as reduced pollinator populations that can contribute to especially damaging to coffee crops, affecting Robusta more than Arabica varieties (Reay, 2016). Such chilling can damage the chloroplasts in coffee plant cells and in turn reducing rates of photosynthesis which is reflected in lower yields and quality of the coffee crop (DaMatta \& Ramalho, 2006). As a consequence, coffee production is reliant on a stable climate envelope to maintain yields and thus farmer livelihoods (Carr, 2000).

\section{Regional climate change impacts}

Global climate patterns are changing rapidly due to anthropogenic greenhouse gas emissions. Within the next two decades, global mean surface temperatures are anticipated to reach at least $1.5^{\circ} \mathrm{C}$ above pre-industrial levels (IPCC, 2021). The consequences of this are severe and diverse: from more frequent extreme weather events, increases in drought, to changes in precipitation patterns and El Niño events, all of which affect agriculture (IPCC, 2021). The effect of local landscapes and climatic zones mean that global patterns of climate change manifest differently between and within regions (Abebe, 2020) (Figure 3), particularly as the tropics are expected to experience the most extreme warming in the short term (IPCC, 2018).

Where temperatures are already high, increasing mean temperatures can be problematic for the development of the coffee fruit (Camargo, 2010). Craparo et al. (2015) note that increasing mean temperature has the greatest influence on coffee crop yields compared with other climatic variables; whilst precipitation change is the main driver of coffee land suitability changes (Bunn et al., 2015a; Läderach et al., 2011). High temperatures can be especially damaging during the sensitive development stage of flowering (Gidey et al., 2020). Unshaded production systems are especially vulnerable to higher temperatures which may cause faster plant growth and overripening of the fruit, lowering bean quality (Camargo, 2010). Changes to patterns and intensity of rainfall will also affect coffee crop development which is dependent on distinctive seasons for its reproductive stages (Bunn et al., 2015a; Camargo, 2010). Ultimately, climate change is likely to decrease coffee yields globally, with a $4-25 \%$ decrease anticipated under agroforestry and 20 $60 \%$ in full-sun systems by 2060 , with the range depending on the climate scenario considered (Gidey et al., 2020)

Areas suitable for coffee cultivation are predicted to decline significantly in the coming decades, particularly for the higher-value Arabica (Bunn et al., 2015a). This land suitability decline is expected to be diverse across regions (

Table 1), although some places, especially upland regions, may become more suitable than at present. Importantly, these data are based on changes in total land suitable for coffee cultivation, rather than land currently used, so may not completely reflect future impacts on production. Increases in atmospheric carbon dioxide $\left(\mathrm{CO}_{2}\right)$ concentrations can increase rates of photosynthesis and improve certain coffee species' heat tolerance which may also influence future areas suitable for cultivation (DaMatta et al., 2019). Critically, there are no countries were identified by Ovalle-Rivera et al. (2015) with overall increases in land suitability for coffee. 


\section{GLOBAL CLIMATE CHANGE TRENDS}

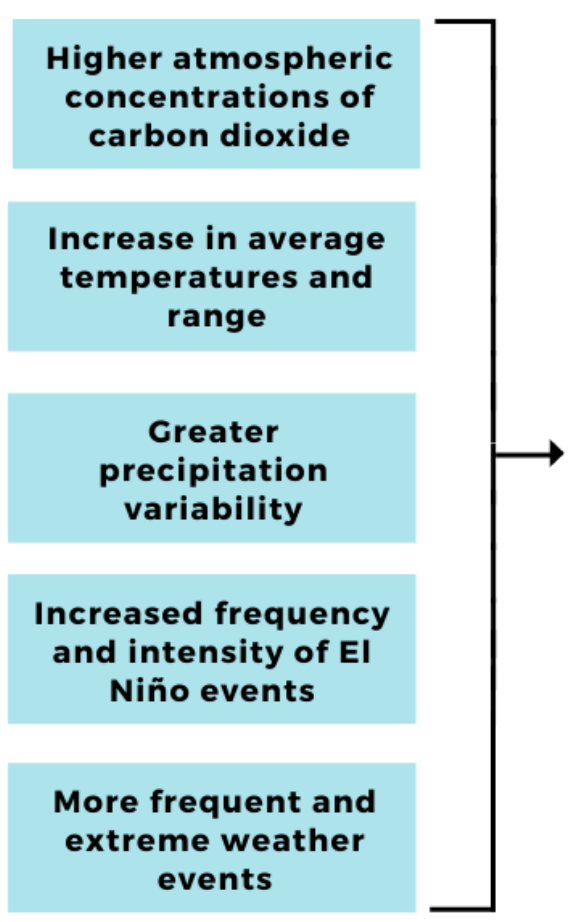

\section{PARTS OF COFFEE PRODUCTION SYSTEMS AFFECTED}

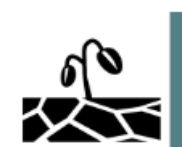

Land suitable for coffee

production

$50 \%$ decrease in land suitable by 2050 (Bunn et al., 2015)
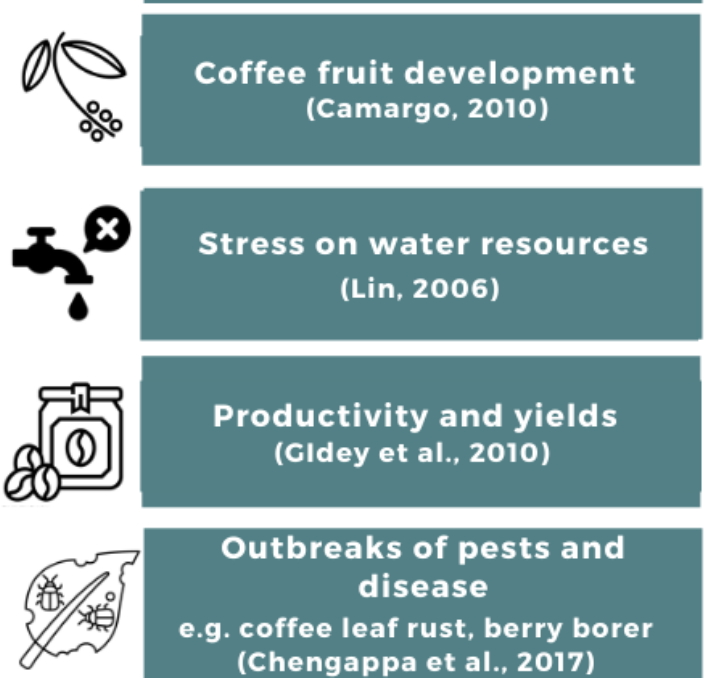

Outbreaks of pests and

disease

e.g. coffee leaf rust, berry borer (Chengappa et al., 2017)

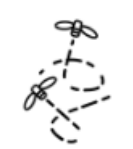

Pollinator diversity and populations

(Boreux et al., 2013)

Figure 3: Global trends of climate change and effects on parts of coffee production systems.

Climate change can have indirect effects on coffee production, in particular the incidence of pests and diseases (Gidey et al., 2020). Jaramillo et al. (2009) found that for each $1^{\circ} \mathrm{C}$ increase in local temperature, the rate of coffee berry borer (Hypothenemus hampel) population growth increases by $8.5 \%$, particularly under drought-stress. The increasing damage and geographical spread of berry borer into higher altitudes have already been observed in East Africa, alongside temperature increases there (Jaramillo et al., 2011). Coffee leaf rust (CLR) (Hemileia vastatrix) is an increasingly problematic fungal disease for coffee producers, particularly as it spreads into areas previously too cold for it to survive (Davis et al., 2019; Avelino et al., 2015). Additionally, numbers of pollinating insects essential for coffee reproduction such as bees are anticipated to decline by 8-18\% under projected climate change scenarios (Imbach et al., 2017). Global climate change patterns are thus increasing the vulnerability of coffee production through several pathways. Building resilience into these systems is, therefore, paramount to mitigating the worst impacts and enhancing ecosystem capacity to absorb climate shocks (IPCC, 2018; Gallopín, 2006).

Table 1: Predicted decrease in land suitable for Arabica cultivation (\%) for selection of leading coffee producers. Area harvested from FAOSTAT (2019)

\begin{tabular}{cccc}
\hline Country & $\begin{array}{c}\text { Area } \\
\text { harvested } \\
\text { for coffee } \\
(\mathrm{ha})^{\star}\end{array}$ & $\begin{array}{c}\text { Decrease in land } \\
\text { suitable for } \\
\text { coffee cultivation } \\
(\%)\end{array}$ & Time period \\
\hline
\end{tabular}




\begin{tabular}{|c|c|c|c|c|}
\hline Nicaragua & 180,416 & 40 & $2015-2050$ & $\begin{array}{c}\text { Quiroga et al., 2020, Baca } \\
\text { et al., } 2014\end{array}$ \\
\hline Guatemala & 308,217 & 19 & 2015-2050 & Ovalle-Rivera et al., 2015 \\
\hline Vietnam & 622,637 & 25 & $2015-2050$ & Ovalle-Rivera et al., 2015 \\
\hline \multirow[t]{2}{*}{ Mexico } & 629,300 & $29-60$ & $2010-2050$ & Schroth et al., 2009 \\
\hline & & 29 & $2015-2050$ & Ovalle-Rivera et al., 2015 \\
\hline \multirow[t]{2}{*}{ Ethiopia } & 758,523 & $\begin{array}{l}65-100 \\
38-90\end{array}$ & $2020-2080$ & $\begin{array}{c}\text { Davis et al., } 2012 \\
\text { (local and area analyses) }\end{array}$ \\
\hline & & 11 & $2015-2050$ & Ovalle-Rivera et al., 2015 \\
\hline Indonesia & $1,258,032$ & $21-37$ & $2015-2050$ & Ovalle-Rivera et al., 2015 \\
\hline Brazil & $1,823,403$ & 25 & $2015-2050$ & Ovalle-Rivera et al., 2015 \\
\hline
\end{tabular}

\section{Long-term changes in coffee production}

\section{Cultivar selection}

Selecting new or different coffee cultivars may offer a viable solution for improving resilience in the longer term but requires long-term consideration of market value, climatic suitability, and management practices for optimal yields. The current dependency on two main species of coffee with limited genetic diversity makes the global coffee production system vulnerable to climate change (Bunn et al., 2015b). Robusta coffee is a lower-grade coffee than Arabica, but more tolerant of higher temperatures and less prone to diseases such as CLR which is increasingly common in Arabica production in Central and South America (Chengappa et al., 2017; Davis et al., 2019). Robusta yields can be double those of Arabica under the same conditions, and since Robusta beans are commonly sold without pulping, less labour is required in the post-harvest stages of production (Ruiz Meza, 2015). However, Robusta is often cultivated in unshaded systems due to its heat tolerance, making these systems more exposed to landslips, soil erosion, extreme weather events and loss of ecosystem services (DaMatta et al., 2007; Ruiz Meza, 2015).

Recent data from Kath et al. (2020) suggests Robusta has a lower optimal temperature range than previously thought, making it less resilient to increased temperatures. Results from this study show that every $1^{\circ} \mathrm{C}$ increase in the mean maximum temperature above about $24^{\circ} \mathrm{C}$ relates to yield reductions of $\sim 14 \%$ (350-460 $\mathrm{kg} \mathrm{ha}^{-1}$ ) (Kath et al., 2020). Hence, transitioning from Arabica to Robusta production may not enhance systems' long-term climate resilience. Pappo et al. (2021) suggest that coffee production can only be sustained through the identification and selection of new cultivars. Catimor coffee is an example of a high-yield cultivar developed in the 1950s from existing Arabica hybrids that is popular in Central and South America as it is more resistant to CLR and produces a higher-grade coffee than Robusta (Bro et al., 2020).

There are over 100 known species of wild coffee. This species pool likely contains beneficial characteristics such as disease resistance and heat tolerance (Davis et al., 2019). The genetic diversity within these coffee wild relatives must be maintained to adapt to changing threats to future production, like resistant pests and disease (Bro et al., 2020). Coffea stenophylla is an example of a wild coffee species originating from West Africa with potential to create more climate resilient coffee production as it grows in annual temperatures $6.2-6.8^{\circ} \mathrm{C}$ hotter on average than Arabica (Davis et al., 2021). Significantly, the flavour profile of stenophylla has greater similarity to Arabica than Robusta and therefore, if its historically low commercial yields can be overcome, could provide greater financial security to coffee farmers (Davis et al., 2021). 
Seed banks can improve farmers' access to different varieties, which may build climate resilience (Shapiro-Garza et al., 2020). Collective seed banks that involve smallholders and operate at a scale larger than independent seed stores, can potentially encourage the identification and preservation of more resilient varieties ( $\mathrm{Li}$ and Pritchard, 2009). However, there are challenges in terms of the social impacts and financial capital required to operate seed banks effectively (Shapiro-Garza et al., 2020). There is also a need to better understand which cultivars may thrive under future environmental conditions, as well as optimising production under current climates (Pappo et al., 2021). This kind of selection for varieties based on future climate change represents a different approach to that identified by Eakin et al. (2014), who found that coffee growers' motivation to adopt different varieties is based on maximising present productivity, yields and disease resistance.

The extinction of wild coffee species presents a significant future challenge. Monoculture coffee production, in addition to deforestation and fragmentation of biodiverse landscapes, increasingly threaten wild coffee populations that contain the genes with potential to provide climate resilience (Aerts et al., 2017). Davis et al. (2019) quantify this threat (Figure 4: IUCN categorisation of extinction risk to known coffee species. Critically endangered (CE), endangered (E), vulnerable (V), near-threatened (NT), least concern (LC), data not available (DA). Data from Davis et al., 2019), using data from the International Union for Conservation of Nature (IUCN) on extinction risk, showing that $60 \%$ of known species of coffee are threatened by extinction.

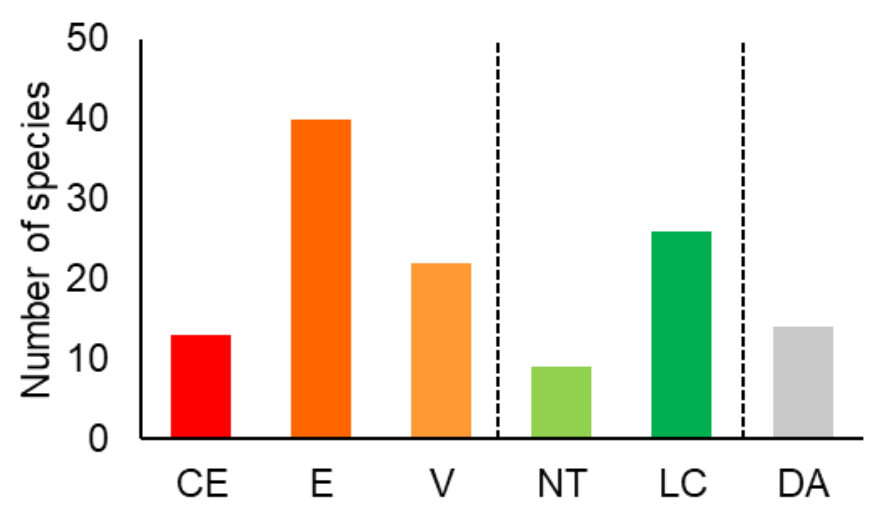

Figure 4: IUCN categorisation of extinction risk to known coffee species. Critically endangered $(\mathrm{CE})$, endangered $(\mathrm{E})$, vulnerable $(\mathrm{V})$, near-threatened (NT), least concern (LC), data not available (DA). Data from Davis et al., 2019.

Given the rate of emerging climatic threats to coffee production; identifying species with the potential to provide secure yields of quality coffee alongside practices that encourage biodiversity are paramount (Bro et al., 2020; Watts, 2016). At present, changing dominant cultivars takes several years and the viability of these also depends on consumer's acceptance and desire for such change.

\section{Altitudinal changes}

The relocation of coffee production to higher altitudes, to address the increases in mean temperatures, has been proposed as a resilience-building strategy, although will require longterm planning (Craparo et al., 2015; Pham et al., 2019; Moat et al., 2017). Land suitability is expected to shift upwards in the coming years (Table 2). In Tanzania, for example, the optimal area for coffee production is estimated to shift upwards by 150-200 masl by 2060 to sustain viable coffee yields and quality (Craparo et al., 2015). Coffee bean quality is thought to benefit from cooler found at air higher elevations, as a slower rate of bean-filling during fruit development is 
284

285

286

287

288

289

290

291

associated with flavourful, acidic coffee (Chemura et al., 2016). The aforementioned effect of higher atmospheric $\mathrm{CO}_{2}$ concentrations that can increase rates of photosynthesis increase and thus, yields may also be enhanced when higher temperatures are moderated at higher elevations (DaMatta et al., 2019). Understanding the impact of higher altitudes and increased atmospheric $\mathrm{CO}_{2}$ on viable coffee yields under different climate change scenarios is critical.

Table 2: Predicted altitudinal changes in land suitability for growing Arabica for a selection of leading coffee producing countries.

\begin{tabular}{lcccc}
\hline Country & $\begin{array}{c}\text { Current altitude } \\
\text { suitable for } \\
\text { Arabica } \\
\text { cultivation } \\
\text { (masl) }\end{array}$ & $\begin{array}{c}\text { Estimated } \\
\text { future optimal } \\
\text { altitude for } \\
\text { Arabica } \\
\text { suitability } \\
\text { (masl) }\end{array}$ & Time period & Reference \\
\hline Mexico & $400-2000$ & $800-2500$ & $2015-2050$ & $\begin{array}{c}\text { Ovalle-Rivera et } \\
\text { al., 2015 }\end{array}$ \\
Brazil & $400-1500$ & $800-1600$ & $2015-2050$ & $\begin{array}{c}\text { Ovalle-Rivera et } \\
\text { al., 2015 }\end{array}$ \\
India & $400-1500$ & $700-1800$ & $2015-2050$ & $\begin{array}{c}\text { Ovalle-Rivera et } \\
\text { al., 2015 } \\
\text { Ovalle-Rivera et }\end{array}$ \\
Ethiopia & $400-2000$ & $800-2500$ & $2015-2050$ & $\begin{array}{c}\text { al., 2015; Gidey et } \\
\text { al., 2020 }\end{array}$ \\
South Africa & $500-1700$ & $700-2000$ & $2015-2050$ & $\begin{array}{c}\text { Ovalle-Rivera et } \\
\text { al., 2015 }\end{array}$ \\
Madagascar & $500-1700$ & $700-2000$ & $2015-2050$ & $\begin{array}{c}\text { Ovalle-Rivera et } \\
\text { al., 2015 }\end{array}$ \\
Indonesia & $500-2000$ & $800-2300$ & $2015-2050$ & $\begin{array}{c}\text { Ovalle-Rivera et } \\
\text { al., 2015 }\end{array}$ \\
Nicaragua & $800-1200$ & $1200-1600$ & $2012-2050$ & $\begin{array}{c}\text { Läderach et al., } \\
\text { 2012 }\end{array}$ \\
Tanzania & $1000-2300$ & $1150-2500$ & $2015-2060$ & $\begin{array}{c}\text { Craparo et al., } \\
\text { 2015 }\end{array}$ \\
\hline
\end{tabular}

292

293

294

295

296

297

298

299

300

301

302

303

304

305

306
Moving production to higher altitudes is constrained by the availability of suitable soil types, water retention, slope gradients, availability of shade trees, and existing land uses (Reay, 2019, Craparo et al., 2015). For example, soil depths tend to be shallower at higher elevations than in lowland areas, whilst greater precipitation and steeper slopes typically can also increase leaching and limit soil nutrients retention (Chemura et al., 2016). In Tanzania, Craparo et al. (2015) noted that higher altitudes often contain protected forests and are sources of rich biodiversity. Deforestation to clear land for coffee production thus has inevitable negative impacts on local biodiversity and $\mathrm{CO}_{2}$ emissions (Ovalle-Rivera et al., 2015). Schroth et al. (2015) therefore suggest that the movement of production should occur in already cleared locations where coffee production can provide a positive impact on the local ecology.

The practicality of moving established coffee production systems is further challenged the 30-50 year lifespan for coffee plants, and the high costs of relocating during this period (Bunn et al., $2015 \mathrm{~b})$. The remoteness of higher-altitude areas can also make managing relocated systems 
difficult. Connectivity to other areas is especially important for labour-intensive crops, as employees need to be able to access the farms relatively easily and cost-effectively (Schroth et al., 2015). The generation time of 5-8 years for coffee before they can be harvested also has implications for the cash flow of coffee businesses (Davis et al., 2012). In areas where shifting altitude is not a viable option and land is predicted to be unsuitable for coffee production, alternative crop, water and soil management strategies should be considered (Läderach et al., 2011).

\section{Soil, water and crop management}

Soil and water resources

Due to the nutrients and soil stability required for crop growth, maintaining soil health is essential for coffee production. However, extreme weather events, nutrient leaching and excessive use of agrochemicals can adversely affect soil health (Reay, 2019). Soil erosion can be reduced through terracing and by planting crops, such as Pennisetum purpureum (elephant grass) that can enhance soil structure (Abebe, 2020). In some steep areas, collaborative soil conservation practices between coffee producers may be important to minimise landslides (Eakin et al., 2014).

Similarly, reliable water supplies are essential for sustaining harvests of high-quality coffee. Under climate change, irregular precipitation may require that more coffee smallholders will require secure means of accessing water to improve the resilience of production systems (Quiroga et al., 2020). Practices that improve water security include those that capture and store precipitation, and that enable access to alternative supplementary sources of water, like borewells, that can be distributed through efficient irrigation systems (Chengappa et al., 2017; Baca et al., 2014). Reliable water supplies and irrigation can enable producers to be more flexible with harvesting patterns, whilst also reducing strain on domestic water supplies (Shapiro-Garza et al., 2020).

Water conservation can be enhanced by increasing the organic matter (OM) content (Camargo, 2010). Applying OM mulches to soil can also increase the water retention in the soil whilst having the additional benefit of suppressing weeds that can reduce the need for agrochemicals (Reay, 2019; Bro et al., 2019). Additional benefits of scale can accrue when carried out through networks or cooperatives of smallholder farmers, for example collective compositing in Chiapas, the most significant coffee producing region in Mexico (Schepp 2009). These practices limit soil erosion and maintain nutrient and water levels enable coffee producers to mitigate some of the risks from climate change, such as drought. Steeper topographies at higher altitudes can be challenging for implementing water-conserving tools (Shapiro-Garza et al., 2020). This is exemplified in the mountainous coffee-producing regions of Southern Mexico which are often too steep for irrigation to be a viable option (Lin, 2009). Here, reducing water loss from the system is an effective mechanism for water conservation, achieved by limiting evapotranspiration under shade trees (Lin, 2009). Financial capital is essential for implementing and maintaining water conservation practices (Shapiro-Garza et al., 2020). Additional crop water requirements under future higher temperatures may also increase the cost of these systems over time, an important consideration when evaluating their sustainability (Chemura et al., 2016).

\section{Coffee crop management}

Improving management of the coffee crop itself may mitigate declines in yields and quality under climate change. Eshetu et al. (2021) found that adjusting the planting date for the crops in SouthWest Ethiopia was an effective practice in mitigating the effects of a delayed wet season. Their research also highlights that importance of farmers being able to access and use meteorological data (Eshetu et al., 2021). Pruning of dead branches to reduce the number of stems per coffee plant is thought to encourage crop growth (Sarmiento-Soler et al., 2020). Dufour et al.'s (2019) study in Sumatra found pruning coffee trees did not change yields significantly in the first year but 
produced over twice the number of ripe berries per tree than unpruned plants in the subsequent year. Effective management of the crop in the post-harvest stages through drying can also build climate resilience. Unlike the more traditional method of drying harvested beans through exposed air-drying, which can expose beans to unpredictable weather conditions and animals; solar dryers that are physical structures which protect the beans and provide more sheltered drying conditions are currently being used in Guatemala and Peru (Shapiro-Garza et al., 2020).

Another opportunity to mitigate increases in temperature and outbreaks of pests and disease under climate change is to select non-coffee crops to substitute or supplement coffee production (Baca et al., 2014). For example, in response to climate change, some coffee farmers in Ethiopia started instead to grow khat: a disease-resistant crop with a tolerance of low water availability; although its viability as an alternative crop is challenged as it is illegal in a number of countries (Abebe, 2020). Similarly, the introduction of trees with harvestable fruit, such as bananas and avocado, into coffee systems in Mexico was found to be a strategy for mitigating climate-induced yield losses, as well as providing additional economic benefits (Ruiz Meza, 2015). However, whilst these methods support producers, it does not provide a sustainable solution for production and consumers of coffee.

\section{Agrochemical inputs}

One of the challenges posed by changing climatic conditions is the effect on the incidence of pests and diseases that affect coffee production. Recent outbreaks of CLR, for example, have caused large economic losses in Central and South America, particularly in the period 2008-2013, with such outbreaks anticipated to become more frequent and widespread (Avelino et al., 2015; Shapiro-Garza et al., 2020).

Effective monitoring of outbreaks is one pathway to building greater resilience so pests can be identified at the source and controlled before they cause wider damage (FAO, 2015). Implementing strategies of identification and reporting beyond the field level, such as through cooperatives, can generate resilience to these outbreaks but they require social and human capital to be successful. In participatory research with smallholder producers in Central America, Shapiro-Garza et al. (2020) found that knowledge regarding pest identification and best practices for integrated pest management (IPM) was uneven and presented a barrier to building resilience.

Beyond monitoring, agrochemical applications are often used to manage pest and disease, although there are negative ecological implications from their use (FAO, 2015). For example, Endosulfan is a commonly used insecticide in coffee production but can be toxic to those applying it in the field and also further down the food chain as it can accumulate in coffee beans (Reay, 2019). There have been successful approaches to mitigating such pest attacks without the use of hazardous agrochemicals (FAO, 2015). For example, coffee cooperatives in Chiapas, Mexico who applied Beauvaria bassiana, a fungus that attacks pests such as coffee borer, as a biological control method (Schepp, 2009). Physical methods of control in Central American include improving the hygiene of the coffee crops themselves, such as manually removing damaged fruits and targeting pests like coffee borers with alcohol-based traps (Reay, 2019). Taking these approaches to limiting the use of agrochemicals in coffee agroforestry production can enhance the bacterial and fungal function and contribute to the overall resilience of the soil system to climate variability (Garzón et al., 2020).

In a survey of coffee farmers in Central America, in response to climatic changes, $17.2 \%$ stated they were applying more fungicides and herbicides, and $14.8 \%$ stated that had increased the use of fertilisers (14.8\%) (Harvey et al., 2018). A similar trend was observed in Mexico following continuous outbreaks of CLR where farmers introduced CLR-resistant coffee cultivars and applied 
more agrochemicals than before (Valencia et al., 2018). Commonly used nitrogen-based fertilisers are also significant sources of nitrous oxide, a potent greenhouse gas that contributes to driving climate change (Salamanca-Jimenez et al., 2017). Reducing fertiliser inputs can provide more sustainable management for coffee production systems which may involve aligning plants' needs for fertiliser with inputs. However, as nitrogen fertilisers are important for delivering high yields per hectare, any reduction that results in lower yields may result in an increase in land-use change elsewhere, thereby resulting in loss of important ecosystem services including carbon sequestration and as a pool of biodiversity. Moreover, this presents a challenge for smallholder farmers lacking readily available technologies for testing plant and soil health to the resolution required. These examples highlight how environmental disturbances driven by climate change can instigate shifts in farmers' application of agrochemicals and management practices.

\section{Agroforestry}

Benefits for production and ecosystem services

Agroforestry involves the incorporation of trees alongside coffee crops to deliver ecological and economic benefits (Figure ). Reported ecological benefits include improved soil health, nutrient cycling, ecosystem biodiversity and carbon storage (Gomes et al., 2020; Garedew et al., 2017). Growing coffee crops under tree canopies creates multi-strata systems that can be further developed through the incorporation of companion crops at different heights (Tschora \& Cherubini, 2020). The shade provided by the trees can protect the coffee crop from temperature extremes (Läderach et al., 2017; Gidey et al., 2020; Camargo, 2010). Agroforestry's economic benefits can include improved economic stability from selling additional crops' produce (Chengappa et al., 2017). Desirable traits for agroforestry species selection include compatibility with coffee, fruit and biomass production, and minimal labour requirements (Souza et al., 2010).



Figure 5: Potential integrated ecological and economic benefits from agroforestry for coffee production including increased above and below ground species biodiversity (a); temperature stabilisation (b); wind speed reduction (c); carbon storage (d); income from tree products (e).

In the wild, coffee grows naturally as an understory crop, and producing coffee under shade trees is a traditional method of cultivating coffee (Bro et al., 2020). Nevertheless, since the 1900s, with the coffee demand growing and the global intensification of agriculture, there has been a shift towards monocultural coffee production characterised by shade trees removal, high coffee crop densities and increased agrochemical inputs (Gidey et al., 2020; Perfecto et al., 2019b). For example, Central American coffee farms are estimated to have lost more than half of their tree cover in the latter half of the twentieth century (Rice, 1999). Globally, just $24 \%$ of coffee is produced under diverse shade systems (Jha et al., 2014). Importantly, the impact of agroforestry 
446

on ecosystem ecology is variable and often depending on the diversity of shade trees planted (Perfecto \& Vandermeer, 2015).

The shade provided by agroforestry trees creates some protection to coffee crops under anticipated increases in mean temperatures (Schroth et al., 2009; Souza et al., 2012; IPCC, 2021). Simultaneously, coffee's vulnerability to low night-time temperatures and frost is reduced through the sheltered microclimate (Gidey et al., 2020). For example, in a Brazilian study, shade trees increased coffee leaf minimum temperatures by $2-4^{\circ} \mathrm{C}$ compared to full-sun systems (Caramori et al., 1996). Likewise, this microclimate reduces temperature fluctuations by approximately $2-3^{\circ} \mathrm{C}$, creating a more stable growing environment (Camargo, 2010). Multiple levels of vegetation and a more stable soil structure under agroforestry than sun-exposed coffee systems can also mitigate the effects of extreme weather events such as hurricanes, floods and landslides that pose high-risk threats to coffee production (Schroth et al., 2009). Wind speed can be reduced by $22-99 \%$ by the presence of trees: compared to full sun systems, limiting damage to coffee fruits and flowers (Coltri et al., 2019; DaMatta et al., 2007). Nonetheless, there is a threshold for the effectiveness of trees; in extreme weather events such as Hurricane Maria in Puerto Rico, Perfecto et al. (2019a) found that this wind protection effect was overridden by the strength of the hurricane.

Shade trees also increase humidity levels around coffee crops. Rates of evapotranspiration from the coffee crops and soil are reduced by $38 \%$ in high-shade systems compared with lower-shade systems, in the Soconusco region of Chiapas, Mexico (Lin 2007). This is important in the context of coffee production as high levels of soil moisture are critical during the flowering stages of the plant's development (Lin, 2010). It is also pertinent to consider the additional water demand associated with planting and maintaining shade trees. Burgess et al. (1998) report that shade trees can redistribute water from deeper within the soil profile into the upper horizons via hydraulic lift. Hence, Lin (2007) suggests that shade trees do not compromise coffee plants' capacity to access soil water and decrease coffee's water loss from evapotranspiration.

The incorporation of shade trees can improve soil structure (Tschora \& Cherubini, 2020). For example, Aguiar (2008) found that after more than a decade of growing coffee alongside trees in South-Eastern Brazil, the soil had greater water retention and a lower bulk density, leading to an overall improvement in the soil quality and nutrient availability to plants. Litterfall can protect the soil surface from run-off during rainfall and replenish soil carbon and nitrogen stocks (Perfecto \& Vandermeer, 2015; Wagner et al., 2021). Such enhancements of nutrient cycling loops through agroforestry embed principles of regenerative agriculture into coffee production systems (Elevitch et al., 2018; Rhodes, 2019). Shade trees further influence the carbon stocks of the area of coffee production, both in terms of soil organic carbon (SOC) and above-ground biomass (Rahn et al., 2014; Häger, 2012; Noponen et al., 2012). Zaro et al.'s (2020) study of coffee production in Brazil found that agroforestry stores $47 \mathrm{Mg} \mathrm{C}$ ha-1 more in the biomass and soil (up to $70 \mathrm{~cm}$ depth) than open coffee systems. Likewise, rates of carbon fixation in plant biomass were found to increase by 5.5-13.9 Mg C ha-1 $\mathrm{yr}^{-1}$ when changing from low to medium and high shade agroforestry in a study of three coffee production systems in Colombia (Andrade and Zapata, 2019). The potential benefits are dependent on the local conditions and management practices. For example, Noponen et al. (2013) reported no change to the soil organic carbon stocks between shaded and unshaded systems over nine years, whilst in the Costa Rica site, above-ground carbon stocks increased by 3.3-12.9 Mg C ha ${ }^{-1} \mathrm{yr}^{-1}$ due to biomass production under agroforestry. Aggregate carbon stocks, including above and below-ground biomass makes agroforestry coffee systems net carbon sinks (Betemariyam et al., 2020). Alongside the ecological benefits, agroforestry has the additional ecosystem service of carbon sequestration, with the potential to reduce further climate change (Soto-Pinto et al., 2010; Rahn et al., 2014). 
Above and below-ground biodiversity is encouraged in the presence of shade trees, particularly when native tree species are planted, in contrast to the common practice of planting exotic species essential ecosystem services can be enhanced through greater biodiversity, for example, reduced pest outbreaks and vulnerability to climate shocks (Perfecto and Vandermeer, 2015; Rice, 1999). For example, the incidence of coffee berry borer was $6.82 \%$ in open-sun production, compared with $0.55 \%$ under shade in Kenya (Jaramillo et al., 2013). Shade trees can also provide pollination services that have great economic value to coffee producers (Chain-Guadarrama et al., 2019; Beer et al., 1998). Bees, amongst other pollinators, are both essential to the production of coffee beans and capable of increasing yields (Boreux et al., 2013). Since areas of coffee production overlap with some of the most biodiverse areas in the world, by conserving diversity through shade coffee systems, forest areas can be connected and used to maintain the movement of migratory birds and other essential pollinators (Jha et al., 2014; Imbach et al., 2017).

While shade trees provide varied benefits to a range of ecosystem services, the impacts on yield are debated (Tschora and Cherubini, 2020). For example, comparing shade and sun systems in Kenya, coffee grown under shade had a greater berry density per branch, $10.8 \%$ more than their sun-grown equivalents (Jaramillo et al., 2013). Moreira et al. (2018) proposed that increases in coffee productivity under palm shade in Brazil was driven by increased soil moisture at a depth of 20-40 cm. Conversely, Lin's (2009) study in Mexico found little difference in the yield and size of the coffee berries produced under high and low shade systems. Finding the optimal spacing and shade tree species to mitigate the effects of climate change whilst maintaining viable yields will be dependent on local conditions and management (Bro et al., 2020). For example, SarmientoSoler et al. (2020) found in Uganda that when shade cover was greater than $30 \%$, the yield was reduced. In Gidey et al.'s (2020) future coffee yield simulations, it was predicted that coffee yields will decline in both shade and monoculture systems, but critically the overall vulnerability of yields to climate change under agroforestry were reduced. DaMatta (2004) also reports that the typical biennial fluctuations in yields experienced in unshaded systems can be replaced with more consistent annual yields under shade.

Shade trees can also impact coffee bean quality, with higher quality reported under shade trees (Bro et al., 2020). The drivers of this were investigated in the lower-altitude coffee-producing areas of Costa Rica where Muschler (2001) found that shade encouraged slower berry ripening resulting in higher-quality, larger, and more uniform beans. Importantly, this study focussed on the coffee production scenarios that were under stress, and therefore, the effect on higher-altitude crops may differ. Ultimately, to have a successful system in which agroforestry benefits coffee production under increasing climatic stresses requires consideration of local conditions, tree selection, spacing, and crop management (DaMatta, 2004).

\section{Challenges and trade-offs}

There are several challenges and trade-offs from more widespread implementation of agroforestry in coffee. Nesper et al. (2019) highlight that the observable trend of creating shade canopies with one species of non-native tree termed 'monospecific shade' systems, limit the ecological benefits and climate resilience of agroforestry (Armbrecht et al., 2004). Limited diversity in the tree species, reduces nutrient cycling in the soil and overall biodiversity compared to more diverse agroforestry systems (Canal-Daza \& Andrade-Castañeda, 2019; Bro et al., 2020).

Planting density and the spacing of trees in these systems is also important to maximise both yields and agroforestry benefits. It was found that coffee planted $4.2 \mathrm{~m}$ away from palm trees produced $0.2 \mathrm{~kg}$ per plant (70\% increase) more than those $1.4 \mathrm{~m}$ away (Moreira et al., 2018). 
Likewise, the coffee species' sensitivity to temperature ranges will also affect the spacing of the trees and the amount of shade required (Craparo et al., 2015). Evidently, the optimal spacing will vary, dependent on the selected tree and coffee species, field conditions and local climate.

Souza et al. (2010) collated a list through a participatory methodology with coffee farmers in Brazil to establish species most suitable to coffee agroforestry. By accounting for the economic and ecological value that specific species can bring to coffee production systems, this list highlights the criteria for selection that are most important to farmers. Examples include Musa paradisiaca and Inga spp. which both have relatively high rates of food and biomass production whilst being compatible with coffee (Souza et al., 2010). The main criteria were compatibility with coffee production (e.g., rooting depth), labour requirements, biomass production and diversity of products from the trees (Souza et al., 2010). The authors emphasise the importance of selection for the success of coffee agroforestry systems and the necessity for farmers to have access to knowledge regarding different tree species and their effect on the ecosystem. Similarly, Dumont et al. (2019) collected a list of 20 tree species from coffee smallholders in Rwanda based on a number of attributes, such as ease of management, rooting depth and timber strength, such as Ficus thonningii. Another consideration is the potential value of harvestable timber or fruit from the trees that can supplement farmer's income, and potentially offset the cost of implementation (Bro et al., 2020). Potential sources of secondary income from the shade trees foreground the interrelation between two climate-adaptation strategies for resilience: income diversification and agroforestry (Nesper et al., 2019).

However, just as coffee crops are affected by the new environmental conditions under climate change, so are trees planted for agroforestry (de Sousa et al., 2019). Habitat suitability in Mesoamerica for popular nitrogen-fixing trees like Erythrina poeppigiana and members of the Inga species will decline significantly by 2050 , particularly in the low-mid altitude areas. Some trees will benefit from the changing environmental conditions, including the fruit tree Brosimum alicastrum and timber trees, such as Simarouba glauca (de Sousa et al., 2019). Therefore, agroforestry management needs to consider the effect of climate change on both the coffee crop and tree species in order to successfully mitigate the impacts of climate change.

There is an additional challenge posed by the potential competition for nutrients, light and water between the trees and coffee crops. Zaro et al. (2020) highlight that competition for such resources is greatest between crops and trees planted close together, but overall, the impacts of competition can be outweighed by the benefits on yield from increased shade. Similarly, the management of the trees, through practices such as pruning and thoughtful species selection can limit such competition (Gomes et al., 2020). Importantly, although greater biodiversity can suppress the incidence of pests, more humid, sheltered conditions under shade can also provide some pests with optimal environments, such as white stem borer, especially at lower altitudes (Chengappa et al., 2017).

\section{Policy and accessibility}

Barriers to implementation

Changing coffee management practices to improve climate resilience involves highly dynamic and multifaceted decision-making processes for farmers and understanding the barriers to improving resilience is critical for building it into these systems (Eakin et al., 2014; Hochachka 2021). These barriers were evident in Harvey et al.'s (2018) research with Central American farmers who despite witnessing climate change impacts, fewer than half responded by changing management practices. The adoption of certain practices (such as relocating production to higher elevations) requires financial capital, as well as technical and social resources which can be prohibitive for some farmers (Baca et al., 2014). For example, integrated pest management is 
most successful through collectively sourced data that necessitates producers to document changes and for the collective itself to be organised and accessible (Shapiro-Garza et al., 2020).

601

602

603

604

A key barrier to implementation is often underlying inequalities, exacerbated by climate change, that limit farmers access to sufficient resources to change management practices (Watts, 2016). Research notes that perceptions of climate risk and capacity to adapt are significantly lower in populations living below poverty lines (Quiroga et al., 2020). Such socio-economic factors influence present climate change vulnerability; how that risk is perceived, and the capacity of farmers to adapt to embed resilience (Chengappa et al., 2017; Nguyen \& Drakou, 2021)). The effect of climate change on the conditions of labour may also present an additional barrier to implementing resilience-building strategies. As a labour-intensive crop, during its management and harvest, those working in production are vulnerable to extreme heat conditions (Kjellstrom et al., 2009). Harsher working may present a barrier to implementing practices such as agroforestry that can increase labour requirements.

\section{Access to knowledge networks}

Many studies highlight how access to farming cooperatives and information about adaptation opportunities can be central to driving sustainable change in adapting management (Barrucand et al., 2017; Abebe, 2020; Quiroga et al., 2015). Importantly, knowledge networks that are most beneficial for encouraging effective adaptation to climate change are those that are grounded in local knowledge and smallholders' experiences of change. Jacobi et al. (2017) suggest that promoting conversations between farmers, as well as local and regional collectives alongside those in policy-making positions would be a strong starting point for overcoming this barrier. Alpízar et al. (2011) found that in Costa Rica, collective dialogue between coffee farmers was pivotal in producing more coordinated responses to change and avoiding high-risk adaptation strategies. Such collective networks facilitate more sustained climate resilience strategies over time (Barrucand et al., 2017; Shapiro-Garza et al., 2020; Baca et al., 2014). Membership of cooperatives and collective organisations has also been found to be a means of driving higher rates of implementation of sustainable farming practices (Bro et al., 2019). For example, Shinbrot et al. (2019) found that in Mexico, membership to groups provided social capital that increased the likelihood of smallholders adopting a range of practices to mitigate climate change. Cooperatives provide knowledge and training for adaptation opportunities and provide important social capital that supports the process of building climate resilience (Bro et al., 2020).

In addition to knowledge about adaptation, Abebe (2020) and Eshetu et al. (2021) highlight the need for accessible and usable climate and meteorological data for farmers. Access to information about climate-related threats to water sources has also been noted as a key source of data for coffee smallholders to use in adaptation decision-making (Quiroga et al., 2015). Transforming data into a resilience-building tool is exemplified by Van Der Wolf et al.'s (2019) tool that inputs local climate data and farmers preferences to generate agroforestry tree species recommendations.

\section{Developing integrated coffee climate resilience strategies}

Building climate resilience into coffee production requires multiscale action, from the field to national and international policy; described by Ramirez-Villegas et al. (2012) as 'traversal measures' enabling widespread change. Practices that drive sustainability in coffee production need to be incentivised to overcome identified financial barriers to implementation. One option is applying financial values to outcomes of adapted practices. Payment for ecosystem services (PES) schemes where producers are rewarded for measurable ecological benefits, like biodiversity, exemplify this (Fain et al., 2018). Addressing underlying economic inequalities through low-interest agricultural loans or subsidies can make adaptation more accessible to 
coffee producers (Bro et al., 2020). Providing access to financial resources is critical for the ability of producers to invest in practices that have upfront costs, such as installing irrigation systems (Baca et al., 2014). Furthermore, instigating change within the coffee market so more sustainable production practices are reflected in the end-product value could also drive positive change. Premium prices of shade-grown beans in sustainable coffee markets reflect such opportunities for resilience-building practices to be more financially viable (Giovannucci \& Koekoek, 2007). Fundamentally, policies that can reduce producers' financial risk of adapting practices have the potential to create systems that are both profitable and ecologically resilient in the long term (Fain et al., 2018).

Creating and improving data systems that coffee producers can easily access, regarding outbreaks of pests and meteorological data may reduce barriers for building resilience (Chengappa et al., 2017). For example, since the epidemics of CLR in Central America, early warning systems have been developed that identify and communicate risks to coffee producers based on weather, economic, ecological and phenological indicators from previous outbreaks (Avelino et al., 2015). Tailoring policies to local conditions, and involving coffee producers themselves are imperative to sustaining production under climate change (Hirons et al., 2018). Local impacts of climate change on coffee production differ dramatically depending on altitude, existing land use and biodiversity, and socioeconomic variables (Jezeer et al., 2019). For example, the priority of coffee farmers reported by Harvey et al. (2018) in Guatemala was agrochemical accessibility, whilst in Costa Rica, technical support was in greatest demand.

Approaching resilience-building as an ongoing, dynamic process is essential given the future possibilities of how climate change could manifest and impact coffee production. Looking broadly at the institutions and networks relating to climate vulnerability and resilience in coffee production will help to create more connected strategies of climate resilience beyond the field scale (Capitani et al., 2019; Eakin et al., 2009).

\section{Conclusions}

Here, we have identified and assessed a range of approaches that can enhance coffee's climate resilience through improved crop, water and soil management. Our review highlights agroforestry as a dominant practise for mitigating climate effects, and is also one of the most financially accessible (Lin, 2007). Other practices, like breeding for more heat and drought tolerant varieties of coffee; conserving water resources, and employing principles of regenerative agriculture, can contribute to the resilience of coffee. Significantly, current climate change trajectories will make large proportions of land currently used to cultivate coffee unviable in the future, whilst opportunities to shift production to higher altitudes are often challenged by sustainability and practicality (Läderach et al., 2011). Hence, although management practices can mitigate some of climate change effects, with the currently cultivated coffee varieties, impacts present long-term threats to production.

While our review identified a range of practices that enhance climate resilience, we show that most studies do not consider the additive effect of using multiple, integrated methods. Undoubtedly, implementing integrated solutions will be central to building climate resilience into coffee production (Haggar \& Schepp, 2012). Therefore, it would be valuable to understand the possibility of applying forms of climate-smart agriculture employed with other crops, like cocoa, to coffee production. Likely a consequence of the greater market share that Arabica coffee has compared with Robusta, there are more knowledge gaps regarding the specific impacts of climate change and thus, adaptation strategies for Robusta. This may become more significant in the future if Arabica yields respond more dramatically to changing climatic conditions than Robusta. In addition, the time scale on which the effects of changing these practices will influence resilience 
701

702

703

704

705

706

707

708

709

710

711

712

713

714

715

716

717

718

719

720

721

722

723

724

725

726

727

728

729

730

731

732

733

734

735

736

737

738

739

740

741

742

743

744

745

746

747

748

749

750

751

is an imperative consideration moving forward as a consequence of the time gap between implementing change and enhanced resilience.

Fundamentally, adaptation to the rapidly changing climate necessitates multiscale collaboration and knowledge-sharing (Fain et al., 2018). Smallholder experiences of cultivating coffee under local climatic conditions are invaluable and need to be part of policy that drives accessible changes to make coffee production more sustainable (Abebe, 2020). There is an urgent need to use existing knowledge of practices that build resilience into the coffee production systems on which millions of people livelihoods depend, as well as driving innovative development of regenerative forms of coffee production that overcome the challenges posed by climate change and preserve ecosystem health.

\section{Acknowledgements}

This study received no specific funding. The authors would like to thank colleagues in the Cranfield School of Water, Energy and Environment for feedback on earlier drafts, as well as the reviewers of this manuscript.

\section{References}

Abebe, G. (2020) 'Dealing with climate change and other stressors: small-scale coffee farmers in the Fero-two Peasant Association in the Wensho district, southern Ethiopia', GeoJournal. Available at: $10.1007 / \mathrm{s} 10708-020-10210-7$

Aerts, R., Geeraert, L., Berecha, G., Hundera, K., Muys, B., De Kort, H. and Honnay, O. (2017) 'Conserving wild Arabica coffee: Emerging threats and opportunities', Agriculture, Ecosystems \& Environment, 237, pp. 75-79.

Aguiar, M.I.D. (2008) 'Qualidade física do solo em sistemas agroflorestais', Master's Thesis. Universidade Federal de Viçosa, Brasil.

Alpízar, F., Carlsson, F. and Naranjo, M.A. (2011) 'The effect of ambiguous risk, and coordination on farmers' adaptation to climate change - A framed field experiment', Ecological Economics, 70(12), pp. 2317-2326.

Andrade, H.J. and Zapata, P.C. (2019) 'Mitigation of climate change of coffee production systems in cundinamarca, colombia', Floresta e Ambiente, 26 Instituto de Florestas da Universidade Federal Rural do Rio de Janeiro. Available at: 10.1590/2179-8087.012618 Armbrecht, I., Perfecto, I. and Vandermeer, J. (2004) 'Enigmatic Biodiversity Correlations: Ant Diversity Responds to Diverse Resources', Science, 304(5668), pp. 284-286.

Avelino, J., Cristancho, M., Georgiou, S., Imbach, P., Aguilar, L., Bornemann, G., Läderach, P., Anzueto, F., Hruska, A.J. and Morales, C. (2015) 'The coffee rust crises in Colombia and Central America (2008-2013): impacts, plausible causes and proposed solutions', Food Security, 7(2), pp. 303-321.

Baca, M., Läderach, P., Haggar, J., Schroth, G. and Ovalle, O. (2014) 'An Integrated Framework for Assessing Vulnerability to Climate Change and Developing Adaptation Strategies for Coffee Growing Families in Mesoamerica', PLoS ONE, 9(2).

Barrucand, M.G., Giraldo Vieira, C. and Canziani, P.O. (2017) 'Climate change and its impacts: perception and adaptation in rural areas of Manizales, Colombia', Climate and Development, 9(5), pp. 415-427.

Beer, J., Muschler, R., Kass, D. and Somarriba, E. (1998) 'Shade management in coffee and cacao plantations', in Nair, P. K. R. and Latt, C. R. (eds.) Directions in Tropical Agroforestry Research. Forestry Sciences. Dordrecht: Springer Netherlands, pp. 139-164. Available at: 10.1007/978-94-015-9008-2 6

Betemariyam, M., Negash, M. and Worku, A. (2020) 'Comparative Analysis of Carbon Stocks in Home Garden and Adjacent Coffee Based Agroforestry Systems in Ethiopia', Small-scale Forestry, 19(3), pp. 319-334. 
Boreux, V., Kushalappa, C.G., Vaast, P. and Ghazoul, J. (2013) 'Interactive effects among ecosystem services and management practices on crop production: Pollination in coffee agroforestry systems', Proceedings of the National Academy of Sciences, 110(21), pp. 83878392.

Bro, A.S., Clay, D.C., Ortega, D.L. and Lopez, M.C. (2019) 'Determinants of adoption of sustainable production practices among smallholder coffee producers in Nicaragua', Environment, Development and Sustainability, 21(2), pp. 895-915. Bro, A.S., Ortega, D.L., Clay, D.C. and Richardson, R.B. (2020) 'Understanding individuals' incentives for climate change adaptation in Nicaragua's coffee sector', Climate and Development, 12(4), pp. 332-342.

Bunn, C., Läderach, P., Jimenez, J.G.P., Montagnon, C. and Schilling, T. (2015a) 'Multiclass Classification of Agro-Ecological Zones for Arabica Coffee: An Improved Understanding of the Impacts of Climate Change', PLOS ONE, 10(10) Public Library of Science, p. e0140490. Bunn, C., Läderach, P., Ovalle Rivera, O. and Kirschke, D. (2015b) 'A bitter cup: climate change profile of global production of Arabica and Robusta coffee', Climatic Change, 129(1-2), pp. 89101.

Burgess, S.S.O., Adams, M.A., Turner, N.C. and Ong, C.K. (1998) 'The redistribution of soil water by tree root systems', Oecologia, 115(3), pp. 306-311.

Camargo, M.B.P. de (2010) 'The impact of climatic variability and climate change on arabic coffee crop in Brazil', Bragantia, 69(1), pp. 239-247.

Canal-Daza, D. and Andrade-Castañeda, H. (2019) 'Adaptation to Climate Change in Coffee Production Systems in Tolima', Floresta e Ambiente, 26(3).

Capitani, C., Garedew, W., Mitiku, A., Berecha, G., Hailu, B.T., Heiskanen, J., Hurskainen, P., Platts, P.J., Siljander, M., Pinard, F., Johansson, T. and Marchant, R. (2019) 'Views from two mountains: exploring climate change impacts on traditional farming communities of Eastern Africa highlands through participatory scenarios', Sustainability Science, 14(1), pp. 191-203. Caramori, P.H., Androcioli Filho, A. and Leal, A.C. (1996) 'Coffee shade with Mimosa scabrella benth. for frost protection in southern Brazil', Agroforestry Systems, 33(3), pp. 205-214.

Carr, M.K.V. (2000). 'The Water relations and irrigation requirements of coffee', Expl. Agric. 37, 1-36.

Castellanos, E.J., Tucker, C., Eakin, H., Morales, H., Barrera, J.F. and Díaz, R. (2013)

'Assessing the adaptation strategies of farmers facing multiple stressors: Lessons from the Coffee and Global Changes project in Mesoamerica', Environmental Science \& Policy, 26, pp. 19-28.

Chain-Guadarrama, A., Martínez-Salinas, A., Aristizábal, N. and Ricketts, T.H. (2019) 'Ecosystem services by birds and bees to coffee in a changing climate: A review of coffee berry borer control and pollination', Agriculture, Ecosystems \& Environment, 280, pp. 53-67. Chemura, A., Kutywayo, D., Chidoko, P. and Mahoya, C. (2016) 'Bioclimatic modelling of current and projected climatic suitability of coffee (Coffea Arabica) production in Zimbabwe', Regional Environmental Change, 16(2), pp. 473-485.

Chengappa, P.G., Devika, C.M. and Rudragouda, C.S. (2017) 'Climate variability and mitigation: perceptions and strategies adopted by traditional coffee growers in India', Climate and Development, 9(7), pp. 593-604.

Coltri, P.P., Pinto, H.S., Gonçalves, R.R. do V., Zullo Junior, J. and Dubreuil, V. (2019) 'Low levels of shade and climate change adaptation of Arabica coffee in southeastern Brazil', Heliyon, 5(2).

Craparo, A.C.W., Van Asten, P.J.A., Läderach, P., Jassogne, L.T.P. and Grab, S.W. (2015) 'Coffea Arabica yields decline in Tanzania due to climate change: Global implications', Agricultural and Forest Meteorology, 207, pp. 1-10.

DaMatta, F.M. (2004) 'Ecophysiological constraints on the production of shaded and unshaded coffee: a review', Field Crops Research, 86(2), pp. 99-114. 
DaMatta, F.M., Rahn, E., Läderach, P., Ghini, R. and Ramalho, J.C. (2019) 'Why could the

804

805

806

807

808

809

810

811

812

813

814

815

816

817

818

819

820

821

822

823

824

825

826

827

828

829

830

831

832

833

834

835

836

837

838

839

840

841

842

843

844

845

846

847

848

849

850

851

852

853 coffee crop endure climate change and global warming to a greater extent than previously estimated?', Climatic Change, 152(1), pp. 167-178.

DaMatta, F.M., Ramalho, J.D.C. (2006) 'Impacts of drought and temperature stress on coffee physiology and production: a review', Brazilian Journal of Plant Physiology, 18(1).

DaMatta, F.M., Ronchi, C.P., Maestri, M. and Barros, R.S. (2007) 'Ecophysiology of coffee growth and production', Brazilian Journal of Plant Physiology, 19(4), pp. 485-510.

Davis, A.P., Chadburn, H., Moat, J., O'Sullivan, R., Hargreaves, S. and Lughadha, E.N. (2019) 'High extinction risk for wild coffee species and implications for coffee sector sustainability', Science Advances, 5(1).

Davis, A.P., Gole, T.W., Baena, S. and Moat, J. (2012) 'The Impact of Climate Change on Indigenous Arabica Coffee (Coffea Arabica): Predicting Future Trends and Identifying Priorities', PLOS ONE, 7(11).

Davis, A.P., Mieulet, D., Moat, J., Sarmu, D. and Haggar, J. (2021) 'Arabica-like flavour in a heat-tolerant wild coffee species', Nature Plants, 7(4), pp. 413-418.

Devagiri, G.M., Khaple, A.K., Anithraj, H.B., Kushalappa, C.G., Krishnappa, A.K. and Mishra, S.B. (2020) 'Assessment of tree diversity and above-ground biomass in coffee agroforest dominated tropical landscape of India's Central Western Ghats', Journal of Forestry Research, 31(3), pp. 1005-1015.

Dufour, B.P., Kerana, I.W. and Ribeyre, F. (2019) 'Effect of coffee tree pruning on berry production and coffee berry borer infestation in the Toba Highlands (North Sumatra)', Crop Protection, 122, pp. 151-158.

Eakin, H., Tucker, C.M., Castellanos, E., Diaz-Porras, R., Barrera, J.F. and Morales, H. (2014)

'Adaptation in a multi-stressor environment: perceptions and responses to climatic and economic risks by coffee growers in Mesoamerica', Environment, Development and Sustainability, 16(1), pp. 123-139.

Eakin, H., Winkels, A. and Sendzimir, J. (2009) 'Nested vulnerability: exploring cross-scale linkages and vulnerability teleconnections in Mexican and Vietnamese coffee systems', Environmental Science \& Policy, 12(4), pp. 398-412.

Elevitch, C.R., Mazaroli, D.N. and Ragone, D. (2018) 'Agroforestry Standards for Regenerative Agriculture', Sustainability, 10(9) Multidisciplinary Digital Publishing Institute.

Eshetu, G., Johansson, T., Garedew, W. and Yisahak, T. (2021) 'Determinants of smallholder farmers' adaptation options to climate change in a coffee-based farming system of Southwest Ethiopia', Climate and Development, 13(4) Taylor \& Francis, pp. 318-325.

Fain S.J., Quiñones M., Álvarez-Berríos N.L., Parés-Ramos I.K., Gould W.A. (2018) 'Climate change and coffee: assessing vulnerability by modeling future climate suitability in the Caribbean island of Puerto Rico' Climatic Change, 146, 1-2.

FAO (2015) 'Phasing out Highly Hazardous Pesticides is possible! Farmer experiences in growing coffee without endosulfan', Available at: http://www.fao.org/3/i4573e/i4573e.pdf [Accessed 10 July 2021].

FAOSTAT (2019) Crop and livestock products, Available at: http://www.fao.org/3/i4573e/i4573e.pdf [Accessed 15 June 2021].

Gallopín, G.C. (2006) 'Linkages between vulnerability, resilience, and adaptive capacity', Global Environmental Change, 16(3), pp. 293-303.

Garedew, W., Hailu, B.T., Lemessa, F., Pellikka, P. and Pinard, F. (2017) 'Coffee Shade Tree Management: An Adaptation Option for Climate Change Impact for Small Scale Coffee Growers in South-West Ethiopia', in Leal Filho, W., Belay, S., Kalangu, J., Menas, W., Munishi, P. and Musiyiwa, K. (eds.) Climate Change Adaptation in Africa. Climate Change Management. Cham: Springer International Publishing, pp. 647-659. Available at: 10.1007/978-3-319-49520-0 40 Garzón, A.F., Rivas, L.P.P. and Avellaneda-Torres, L.M. (2020) 'Effect of management (ecological and conventional) on functional groups of soil microorganisms in coffee 
854

855

856

857

858

859

860

861

862

863

864

865

866

867

868

869

870

871

872

873

874

875

876

877

878

879

880

881

882

883

884

885

886

887

888

889

890

891

892

893

894

895

896

897

898

899

900

901

902

903

agroecosystems with different resilience to climate variability, Colombia', Acta Scientiarum. Biological Sciences, 42. Available at: https://www.redalyc.org/journal/1871/187163790018/movil/

Gidey, T., Oliveira, T.S., Crous-Duran, J. and Palma, J.H.N. (2020) 'Using the yield-SAFE model to assess the impacts of climate change on yield of coffee (Coffea Arabica L.) under agroforestry and monoculture systems', Agroforestry Systems, 94(1), pp. 57-70.

Giovannucci, D. and Koekoek, F.J. (2007) The State of Sustainable Coffee: A Study of Twelve Major Markets. Rochester, NY: Social Science Research Network. Available at: https://papers.ssrn.com/abstract=996763

Gomes, L.C., Bianchi, F.J.J.A., Cardoso, I.M., Fernandes, R.B.A., Filho, E.I.F. and Schulte, R.P.O. (2020) 'Agroforestry systems can mitigate the impacts of climate change on coffee production: A spatially explicit assessment in Brazil', Agriculture, Ecosystems \& Environment, 294.

Häger, A. (2012) 'The effects of management and plant diversity on carbon storage in coffee agroforestry systems in Costa Rica', Agroforestry Systems, 86(2), pp. 159-174.

Hammersley, M. (2001) 'On "Systematic" Reviews of Research Literatures: A "narrative" response to Evans \& Benefield', British Educational Research Journal, 27(5), pp. 543-554. Harvey, C.A., Saborio-Rodríguez, M., Martinez-Rodríguez, M.R., Viguera, B., ChainGuadarrama, A., Vignola, R. and Alpizar, F. (2018) 'Climate change impacts and adaptation among smallholder farmers in Central America', Agriculture \& Food Security, 7(1), p. 57. Hirons, M., Mehrabi, Z., Gonfa, T.A., Morel, A., Gole, T.W., McDermott, C., Boyd, E., Robinson, E., Sheleme, D., Malhi, Y., Mason, J. and Norris, K. (2018) 'Pursuing climate resilient coffee in Ethiopia - A critical review', Geoforum, 91, pp. 108-116.

Hochachka, G. (2021) 'Integrating the four faces of climate change adaptation: Towards transformative change in Guatemalan coffee communities', World Development, 105361 Imbach, P., Fung, E., Hannah, L., Navarro-Racines, C.E., Roubik, D.W., Ricketts, T.H., Harvey, C.A., Donatti, C.I., Läderach, P., Locatelli, B. and Roehrdanz, P.R. (2017) 'Coupling of pollination services and coffee suitability under climate change', Proceedings of the National Academy of Sciences, 114(39), pp. 10438-10442.

IPCC (2018) 'Summary for Policymakers. In: Global Warming of $1.5^{\circ} \mathrm{C}$. An IPCC Special Report on the impacts of global warming of $1.5^{\circ} \mathrm{C}$ above pre-industrial levels and related global greenhouse gas emission pathways, in the context of strengthening the global response to the threat of climate change, sustainable development, and efforts to eradicate poverty' [MassonDelmotte, V., P. Zhai, H.-O. Pörtner, D. Roberts, J. Skea, P.R. Shukla, A. Pirani, W. MoufoumaOkia, C. Péan, R. Pidcock, S. Connors, J.B.R. Matthews, Y. Chen, X. Zhou, M.I. Gomis, E. Lonnoy, T. Maycock, M. Tignor, and T. Waterfield (eds.)]. World Meteorological Organization, Geneva, Switzerland. Available at: https://www.ipcc.ch/sr15/

IPCC (2021) Climate Change 2021: The Physical Science Basis. Contribution of Working Group I to the Sixth Assessment Report of the Intergovernmental Panel on Climate Change Cambridge University Press.

Jacobi, J., Mathez-Stiefel, S.-L., Gambon, H., Rist, S. and Altieri, M. (2017) 'Whose Knowledge, Whose Development? Use and Role of Local and External Knowledge in Agroforestry Projects in Bolivia', Environmental Management, 59(3), pp. 464-476.

Jaramillo, J., Chabi-Olaye, A., Kamonjo, C., Jaramillo, A., Vega, F.E., Poehling, H.-M. and Borgemeister, C. (2009) 'Thermal Tolerance of the Coffee Berry Borer Hypothenemus hampei: Predictions of Climate Change Impact on a Tropical Insect Pest', PLOS ONE, 4(8) Public Library of Science, p. e6487.

Jaramillo, J., Muchugu, E., Vega, F.E., Davis, A., Borgemeister, C. and Chabi-Olaye, A. (2011) 'Some like it hot: the influence and implications of climate change on coffee berry borer (Hypothenemus hampei) and coffee production in East Africa', PloS One, 6(9), p. e24528. 
904

905

906

907

908

909

910

911

912

913

914

915

916

917

918

919

920

921

922

923

924

925

926

927

928

929

930

931

932

933

934

935

936

937

938

939

940

941

942

943

944

945

946

947

948

949

950

951

952

953

Jaramillo, J., Setamou, M., Muchugu, E., Chabi-Olaye, A., Jaramillo, A., Mukabana, J., Maina, J., Gathara, S. and Borgemeister, C. (2013) 'Climate Change or Urbanization? Impacts on a Traditional Coffee Production System in East Africa over the Last 80 Years', PLOS ONE, 8(1), p. e51815.

Jezeer, R.E., Verweij, P.A., Boot, R.G.A., Junginger, M. and Santos, M.J. (2019) 'Influence of livelihood assets, experienced shocks and perceived risks on smallholder coffee farming practices in Peru', Journal of Environmental Management, 242, pp. 496-506.

Jha, S., Bacon, C.M., Philpott, S.M., Ernesto Méndez, V., Läderach, P. and Rice, R.A. (2014)

'Shade Coffee: Update on a Disappearing Refuge for Biodiversity', BioScience, 64(5), pp. 416428.

Kath, J., Byrareddy, V.M., Craparo, A., Nguyen-Huy, T., Mushtaq, S., Cao, L. and Bossolasco, L. (2020) 'Not so robust: Robusta coffee production is highly sensitive to temperature', Global Change Biology, 26(6), pp. 3677-3688.

Kjellstrom, T., Holmer, I. and Lemke, B. (2009) 'Workplace heat stress, health and productivity an increasing challenge for low and middle-income countries during climate change', Global Health Action, 2.

Läderach, P., Lundy, M., Jarvis, A., Ramirez, J., Portilla, E.P., Schepp, K. and Eitzinger, A. (2011) 'Predicted Impact of Climate Change on Coffee Supply Chains', Leal Filho, W. (ed.) The Economic, Social and Political Elements of Climate Change. Berlin, Heidelberg: Springer. Climate Change Management, pp. 703-723.

Läderach, P., Ramirez-Villegas, J., Navarro-Racines, C., Zelaya, C., Martinez-Valle, A. and Jarvis, A. (2017) 'Climate change adaptation of coffee production in space and time', Climatic Change, 141(1), pp. 47-62.

Li, D.-Z. and Pritchard, H.W. (2009) 'The science and economics of ex situ plant conservation', Trends in Plant Science, 14(11), pp. 614-621.

Lin, B.B. (2007) 'Agroforestry management as an adaptive strategy against potential microclimate extremes in coffee agriculture', Agricultural and Forest Meteorology, 144(1-2), pp. 85-94.

Lin, B.B. (2009) 'Coffee ( Café Arabica var. Bourbon) Fruit Growth and Development Under Varying Shade Levels in the Soconusco Region of Chiapas, Mexico', Journal of Sustainable Agriculture, 33(1), pp. 51-65.

Lin, B.B. (2010) 'The role of agroforestry in reducing water loss through soil evaporation and crop transpiration in coffee agroecosystems', Agricultural and Forest Meteorology, 150(4), pp. 510-518.

Moat, J., Williams, J., Baena, S., Wilkinson, T., Gole, T.W., Challa, Z.K., Demissew, S. and Davis, A.P. (2017) 'Resilience potential of the Ethiopian coffee sector under climate change', Nature Plants, 3(7), pp. 1-14.

Moreira, S.L.S., Pires, C.V., Marcatti, G.E., Santos, R.H.S., Imbuzeiro, H.M.A. and Fernandes, R.B.A. (2018) 'Intercropping of coffee with the palm tree, macauba, can mitigate climate change effects', Agricultural and Forest Meteorology, 256-257, pp. 379-390.

Muschler, R.G. (2001) 'Shade improves coffee quality in a sub-optimal coffee-zone of Costa Rica', Agroforestry Systems, 85, pp. 131-139.

Nardini A., Õunapuu-Pikas E., Savi T. (2014) 'When smaller is better: Leaf hydraulic conductance and drought vulnerability correlate to leaf size and venation density across four Coffea arabica genotypes'. Functional Plant Biology, 41, 9.

Nesper, M., Kueffer, C., Krishnan, S., Kushalappa, C.G. and Ghazoul, J. (2019) 'Simplification of shade tree diversity reduces nutrient cycling resilience in coffee agroforestry', Journal of Applied Ecology, 56(1), pp. 119-131.

Nguyen N., Drakou E.G. (2021) 'Farmers intention to adopt sustainable agriculture hinges on climate awareness: The case of Vietnamese coffee', Journal of Cleaner Production, 126828 
954

955

956

957

958

959

960

961

962

963

964

965

966

967

968

969

970

971

972

973

974

975

976

977

978

979

980

981

982

983

984

985

986

987

988

989

990

991

992

993

994

995

996

997

998

999

1000

1001

1002

Noponen, M.R.A., Edwards-Jones, G., Haggar, J.P., Soto, G., Attarzadeh, N. and Healey, J.R. (2012) 'Greenhouse gas emissions in coffee grown with differing input levels under conventional and organic management', Agriculture, Ecosystems \& Environment, 151, pp. 6-15.

Noponen, M.R.A., Healey, J.R., Soto, G. and Haggar, J.P. (2013) 'Sink or source-The potential of coffee agroforestry systems to sequester atmospheric CO2 into soil organic carbon', Agriculture, Ecosystems \& Environment, 175, pp. 60-68.

Ovalle-Rivera, O., Läderach, P., Bunn, C., Obersteiner, M. and Schroth, G. (2015) 'Projected Shifts in Coffea Arabica Suitability among Major Global Producing Regions Due to Climate Change', PLOS ONE, 10(4), p. e0124155.

Pappo, E., Wilson, C. and Flory, S.L. (2021) 'Hybrid coffee cultivars may enhance agroecosystem resilience to climate change', AoB PLANTS, 13(2). Available at: 10.1093/aobpla/plab010

Perfecto, I., Hajian-Forooshani, Z., Iverson, A., Irizarry, A.D., Lugo-Perez, J., Medina, N., Vaidya, C., White, A. and Vandermeer, J. (2019a) 'Response of Coffee Farms to Hurricane Maria: Resistance and Resilience from an Extreme Climatic Event', Scientific Reports, 9, p. 15668.

Perfecto, I., Jiménez-Soto, M.E. and Vandermeer, J. (2019b) 'Coffee Landscapes Shaping the Anthropocene: Forced Simplification on a Complex Agroecological Landscape', Current Anthropology, 60(S20), pp. S236-S250.

Perfecto, I. and Vandermeer, J.H. (2015) Coffee agroecology: a new approach to understanding agricultural biodiversity, ecosystem services, and sustainable development. London; New York: Routledge.

Pham, Y., Reardon-Smith, K., Mushtaq, S. and Cockfield, G. (2019) 'The impact of climate change and variability on coffee production: a systematic review', Climatic Change, 156(4), pp. 609-630.

Pickering, C., Grignon, J., Steven, R., Guitart, D. and Byrne, J. (2015) 'Publishing not perishing: how research students transition from novice to knowledgeable using systematic quantitative literature reviews', Studies in Higher Education, 40(10), pp. 1756-1769.

Quiroga, S., Suárez, C., Diego Solís, J. and Martinez-Juarez, P. (2020) 'Framing vulnerability and coffee farmers' behaviour in the context of climate change adaptation in Nicaragua', World Development, 126, p. 104733.

Quiroga, S., Suárez, C. and Solís, J.D. (2015) ‘Exploring coffee farmers’ awareness about climate change and water needs: Smallholders' perceptions of adaptive capacity', Environmental Science \& Policy, 45, pp. 53-66.

Rahn, E., Läderach, P., Baca, M., Cressy, C., Schroth, G., Malin, D., van Rikxoort, H. and Shriver, J. (2014) 'Climate change adaptation, mitigation and livelihood benefits in coffee production: where are the synergies?', Mitigation and Adaptation Strategies for Global Change, 19(8), pp. 1119-1137.

Ramirez-Villegas, J., Salazar, M., Jarvis, A. and Navarro-Racines, C.E. (2012) 'A way forward on adaptation to climate change in Colombian agriculture: perspectives towards 2050', Climatic Change, 115(3-4), pp. 611-628.

Reay, D. (2019) 'Climate-Smart Coffee', in Reay, D. (ed.) Climate-Smart Food. Cham: Springer International Publishing, pp. 93-104. Available at: 10.1007/978-3-030-18206-9 8

Rhodes, C.J. (2017) 'The Imperative for Regenerative Agriculture', Science Progress, 100(1)

SAGE Publications Ltd, pp. 80-129.

Rice, R.A. (1999) 'A Place Unbecoming: The Coffee Farm of Northern Latin America*',

Geographical Review, 89(4), pp. 554-579.

Ritchie, H. (2018) Coffee bean production [map], Our World in Data, Available at: https://ourworldindata.org/grapher/coffee-bean-production (Accessed: 13 July 2021). 
1003

1004

1005

1006

1007

1008

1009

1010

1011

1012

1013

1014

1015

1016

1017

1018

1019

1020

1021

1022

1023

1024

1025

1026

1027

1028

1029

1030

1031

1032

1033

1034

1035

1036

1037

1038

1039

1040

1041

1042

1043

1044

1045

1046

1047

1048

1049

1050

1051

1052

Ruiz Meza, L.E. (2015) 'Adaptive capacity of small-scale coffee farmers to climate change impacts in the Soconusco region of Chiapas, Mexico', Climate and Development, 7(2), pp. 100109.

Salamanca-Jimenez, A., Doane, T.A. and Horwath, W.R. (2017) 'Nitrogen Use Efficiency of Coffee at the Vegetative Stage as Influenced by Fertilizer Application Method', Frontiers in Plant Science, 8 Frontiers Available at: 10.3389/fpls.2017.00223

Santos, C.A.F. dos, Leitao, A.E., Pais, I.P., Lidon, F.C. and Ramalho, J.C. (2015) 'Perspectives on the potential impacts of climate changes on coffee plant and bean quality', Emirates Journal of Food and Agriculture, , pp. 152-163.

Sarmiento-Soler, A., Vaast, P., Hoffmann, M.P., Jassogne, L., van Asten, P., Graefe, S. and Rötter, R.P. (2020) 'Effect of cropping system, shade cover and altitudinal gradient on coffee yield components at Mt. Elgon, Uganda', Agriculture, Ecosystems \& Environment, 295, p. 106887.

Schepp, K. (2009) 'Smallholders adapt to climate change', Appropriate Technology, 36(3) Burnham, United Kingdom: Research Information Ltd., pp. 64-67.

Schroth, G., Läderach, P., Blackburn Cuero, D.S., Neilson, J. and Bunn, C. (2015) 'Winner or loser of climate change? A modeling study of current and future climatic suitability of Arabica coffee in Indonesia', Regional Environmental Change, 15(7), pp. 1473-1482.

Schroth, G., Laderach, P., Dempewolf, J., Philpott, S., Haggar, J., Eakin, H., Castillejos, T., Garcia Moreno, J., Soto Pinto, L., Hernandez, R., Eitzinger, A. and Ramirez-Villegas, J. (2009)

'Towards a climate change adaptation strategy for coffee communities and ecosystems in the Sierra Madre de Chiapas, Mexico', Mitigation and Adaptation Strategies for Global Change, 14(7), pp. 605-625.

Shapiro-Garza, E., King, D., Rivera-Aguirre, A., Wang, S. and Finley-Lezcano, J. (2020) 'A participatory framework for feasibility assessments of climate change resilience strategies for smallholders: lessons from coffee cooperatives in Latin America', International Journal of Agricultural Sustainability, 18(1), pp. 21-34.

Shinbrot, X.A., Jones, K.W., Rivera-Castañeda, A., López-Báez, W. and Ojima, D.S. (2019) 'Smallholder Farmer Adoption of Climate-Related Adaptation Strategies: The Importance of Vulnerability Context, Livelihood Assets, and Climate Perceptions', Environmental Management, 63(5), pp. 583-595.

Dumont, E.S., Gassner, A., Agaba, G., Nansamba, R. and Sinclair, F. (2019) 'The utility of farmer ranking of tree attributes for selecting companion trees in coffee production systems', Agroforestry Systems, 93(4), pp. 1469-1483.

Soto-Pinto, L., Anzueto, M., Mendoza, J., Ferrer, G.J. and de Jong, B. (2010) 'Carbon sequestration through agroforestry in indigenous communities of Chiapas, Mexico', Agroforestry Systems, 78(1), pp. 39-51.

de Sousa, K., van Zonneveld, M., Holmgren, M., Kindt, R. and Ordoñez, J.C. (2019) 'The future of coffee and cocoa agroforestry in a warmer Mesoamerica', Scientific Reports, 9(1) Nature Publishing Group.

Souza, H.N., Cardoso, I.M., Fernandes, J.M., Garcia, F.C.P., Bonfim, V.R., Santos, A.C., Carvalho, A.F. and Mendonça, E.S. (2010) 'Selection of native trees for intercropping with coffee in the Atlantic Rainforest biome', Agroforestry Systems, 80(1), pp. 1-16.

Souza, H.N. de, de Goede, R.G.M., Brussaard, L., Cardoso, I.M., Duarte, E.M.G., Fernandes, R.B.A., Gomes, L.C. and Pulleman, M.M. (2012) 'Protective shade, tree diversity and soil properties in coffee agroforestry systems in the Atlantic Rainforest biome', Agriculture, Ecosystems \& Environment, 146(1), pp. 179-196.

Tschora, H. and Cherubini, F. (2020) 'Co-benefits and trade-offs of agroforestry for climate change mitigation and other sustainability goals in West Africa', Global Ecology and

Conservation, 22. 
1053 Valencia, V., García-Barrios, L., Sterling, E.J., West, P., Meza-Jiménez, A. and Naeem, S. 1054 (2018) 'Smallholder response to environmental change: Impacts of coffee leaf rust in a forest 1055 frontier in Mexico', Land Use Policy, 79, pp. 463-474.

1056 Van Der Wolf, J., Jassogne, L., Gram, G. and Vaast, P. (2019) 'Turning local knowledge on 1057 agroforestry into an online decision-support tool for tree selection in smallholders' farms', 1058 Experimental Agriculture, 55(S1), pp. 50-66.

1059 Watts, C (2016) 'A Brewing Storm: The climate change risks to coffee', available at:

1060 https://files.fairtrade.net/publications/2016 TCl ABrewingStorm.pdf [Accessed 10 July 2021].

1061 Zaro, G.C., Caramori, P.H., Yada Junior, G.M., Sanquetta, C.R., Filho, A.A., Nunes, A.L.P., 1062 Prete, C.E.C. and Voroney, P. (2020) 'Carbon sequestration in an agroforestry system of coffee 1063 with rubber trees compared to open-grown coffee in southern Brazil', Agroforestry Systems, 1064 94(3), pp. 799-809.

1065 Zullo, J., Pinto, H.S., Assad, E.D. and de Ávila, A.M.H. (2011) 'Potential for growing Arabica 1066 coffee in the extreme south of Brazil in a warmer world', Climatic Change, 109(3-4), pp. 5351067548. 